\title{
Molecular Relationships and Classification of Some Viridans Streptococci as Streptococcus oralis and Emended Description of Streptococcus oralis (Bridge and Sneath 1982)
}

\author{
RENATE KILPPER-BÄLZ, PETER WENZIG, AND KARL HEINZ SCHLEIFER* \\ Lehrstuhl für Mikrobiologie, Technische Universität München, D-8000 Munich 2, Federal Republic of Germany
}

\begin{abstract}
Nucleic acid hybridization studies together with a chemical cell wall analysis and physiological data indicated that some strains designated as Streptococcus sanguis II, Streptococcus sp. ("S. mitior"-S. sanguis), and " $S$. viridans" I, II, and IV are closely related to the type strain of $S$. oralis. These strains contained a directly cross-linked peptidoglycan with lysine as a diamino acid and ribitol and choline as characteristic cell wall constituents. We propose that these strains be classified as members of $S$. oralis. An emended description of $S$. oralis is given. $S$. oralis strains are genetically related to $S$. pneumoniae strains, and representatives of both species contain ribitol and choline in their cell walls.
\end{abstract}

Viridans streptococci are a heterogeneous group of bacteria which are found predominantly in the upper respiratory tract (17). However, they are also an important cause of endocarditis and bacteremia $(8,15,18,23)$. The fact that viridans streptococci cannot be classified by group antigens or other serological methods led to many attempts to separate them on the basis of different physiological and biochemical characteristics $(3,10-14,24)$. However, the results have not been satisfactory for two reasons. First, most authors only studied certain strains of viridans streptococci, and second, there is much confusion in the nomenclature of these organisms. There are, for example, species such as "Streptococcus viridans" and " $S$. mitior" that are not validly described; therefore, no type strains are available. The same strains may even be allocated to different species depending on the author. Thus, strains designated by Colman and Williams (3) as " $S$. mitior" were classified by Facklam (10) as $S$. mitis or $S$. sanguis II. A recently described new species, $S$. oralis, shares typical physiological characteristics with some strains designated as "S. mitior" and $S$. sanguis II (1). The subdivision of " $S$. viridans" and $S$. sanguis into various biotypes caused further confusion in the classification of viridans streptococci.

Other oral streptococci, such as "S. milleri," S. mutans, and related organisms, are also often regarded as viridans streptococci (17). However, recent studies from our laboratory have revealed that strains designated as "S. milleri" belong to either $S$. anginosus or $S$. constellatus (22). Moreover, we confirmed the finding of Coykendall $(4,5)$ that strains of $S$. mutans can be divided into five species, namely, $S$. cricetus, $S$. ferus, $S$. mutans, $S$. rattus, and $S$. sobrinus, which can easily be differentiated (29).

In this study, strains of ' $S$. mitior,' $S$. mitis, S. oralis, $S$. pneumoniae, $S$. salivarius, $S$. sanguis I and II, group-O Streptococcus spp., and "S. viridans" I, II, III, and IV (32) were compared with previously studied oral streptococci. Relationships were determined primarily by nucleic acid homology experiments and cell wall analysis.

\section{MATERIALS AND METHODS}

The strains included in this study are shown in Table 1. They were cultivated in CASO-bouillon (E. Merck AG, Darmstadt, Federal Republic of Germany) at $35^{\circ} \mathrm{C}$ without

\footnotetext{
* Corresponding author.
}

aeration. Cells were harvested at the end of the exponential growth phase for the isolation of deoxyribonucleic acid (DNA) and at the stationary growth phase for the preparation of cell walls. Isolation of DNA and ribosomal ribonucleic acid, radioactive labeling, and nucleic acid hybridization experiments were carried out by the filter method as described previously $(19,20,22)$. DNA base composition was determined by thermal denaturation with a Gilford model 2600 spectrophotometer (16). DNA from Escherichia coli $\mathrm{K}-12$ was used as the standard. The guanine-plus-cytosine $(\mathrm{G}+\mathrm{C})$ contents (in moles percent) were calculated by the method of De Ley (7) and were corrected with the published value for $E$. coli, $51.7 \mathrm{~mol} \%$ (7). Isolation of cell walls and determination of peptidoglycan types and cell wall sugar compositions were carried out as previously described (26, 27). Cell wall teichoic acids were analyzed by the method of Endl et al. (9). Choline was determined in cell wall hydrolysates ( $2 \mathrm{mg}$ of cell wall, $0.2 \mathrm{ml}$ of $2 \mathrm{M} \mathrm{HCl}, 3 \mathrm{~h}, 100^{\circ} \mathrm{C}$ ) by thin-layer chromatography (33) and enzymatically with choline oxidase by the method of Takayama et al. (34), except that for the determination of hydrogen peroxide, 2-hydroxy3,5-dichlorobenzene sulfonate (35) was used instead of phenol. Physiological characteristics were determined by conventional tests as described by Facklam and Wilkinson (11) and Bucher and von Graevenitz (2).

\section{RESULTS AND DISCUSSION}

Cell wall analysis and DNA base composition. Determinations of peptidoglycan types showed that $S$. oralis, "S. viridans" I, II, III, and IV (32), strains designated as $S$. sanguis II, strains obtained as ' $S$. mitior' $-S$. sanguis, and group-O Streptococcus spp. contained the peptidoglycan type Lys-direct (Table 1). This type of peptidoglycan is not widespread among streptococci and has been found so far only among certain viridans streptococci (27; J. Hladny, Ph.D. thesis, Technische Universität München, Munich, Federal Republic of Germany, 1971) and group-R and -S streptococci (21). All the other "greening," "oral," or "milleri" streptococci contained different peptidoglycan types $(22,29)$. The most frequent one was Lys-Ala ${ }_{1-3}$, but in the "mutans-like"' streptococci, Lys-Thr-Ala also was found (30). Further characteristic cell wall components of the viridans streptococci containing the Lys-direct peptidoglycan type were ribitol and choline (Table 1). In this respect, they were similar to $S$. pneumoniae. The presence of ribitol 
TABLE 1. Organisms studied, $G+C$ contents, and cell wall data

\begin{tabular}{|c|c|c|c|c|c|c|c|c|c|c|}
\hline \multirow[b]{2}{*}{ Organism } & \multirow[b]{2}{*}{ Strain $^{a}$} & \multirow{2}{*}{$\begin{array}{c}\mathrm{G}+\mathrm{C} \\
\text { content } \\
\text { of DNA } \\
(\mathrm{mol} \%)\end{array}$} & \multirow[b]{2}{*}{$\begin{array}{l}\text { Peptidoglycan } \\
\text { type }\end{array}$} & \multirow[b]{2}{*}{$\begin{array}{c}\text { Ribitol } \\
\text { teichoic } \\
\text { acid }\end{array}$} & \multicolumn{5}{|c|}{ Sugar and amino sugar constituents of cell walls ${ }^{b}$} & \multirow[b]{2}{*}{$\begin{array}{l}\text { Choline } \\
\text { bound } \\
\text { to the } \\
\text { cell wall }\end{array}$} \\
\hline & & & & & Rhamnose & Glucose & $\begin{array}{l}\text { Galac- } \\
\text { tose }\end{array}$ & $\mathrm{GlcNH}_{2}^{c}$ & $\mathrm{GaINH}_{2}{ }^{d}$ & \\
\hline $\begin{array}{l}\text { Streptococcus } \\
\text { acidominimus }\end{array}$ & NCDO $2025^{\mathrm{T}}$ & $\mathrm{ND}^{e}$ & ND & - & + & - & + & $(+)$ & + & - \\
\hline S. anginosus & DSM $20563^{\mathrm{T}}$ & 37 & Lys-Ala $_{1-3}$ & - & + & + & + & - & + & - \\
\hline S. bovis & DSM $20480^{\mathrm{T}}$ & 38 & Lys-Thr-Ala & - & + & + & + & + & - & - \\
\hline S. constellatus & DSM $20575^{\mathrm{T}}$ & 37 & Lys-Ala & - & + & + & - & + & - & + \\
\hline S. cricetus & ATCC $19642^{\mathrm{T}}$ & 40 & Lys-Thr-Ala & - & + & + & + & ND & ND & - \\
\hline S. ferus & ATCC $33477^{\mathrm{T}}$ & 42 & Lys-Ala ${ }_{2-3}$ & - & + & + & - & ND & ND & ND \\
\hline S. iniae & DSM $20576^{\mathrm{T}}$ & 37 & Lys-Ala ${ }_{1-3}$ & - & + & + & + & + & - & - \\
\hline$S$. intermedius & DSM $20573^{\mathrm{T}}$ & 37 & Lys-Ala ${ }_{1-3}$ & - & + & + & - & - & - & - \\
\hline S. lactis & DSM $20481^{\mathrm{T}}$ & 36 & Lys-D-Asp & - & + & + & + & ND & ND & - \\
\hline$S$. mitis & DSM $20568^{\mathrm{T}}$ & 38 & Lys-Ala ${ }_{1-3}$ & - & + & + & + & + & $(+)$ & - \\
\hline S. morbillorum & DSM $20572^{\mathrm{T}}$ & ND & Lys-Ala ${ }_{1-3}$ & - & + & $(+)$ & + & $(+)$ & - & - \\
\hline S. mutans & $\operatorname{ATCC} 25175^{\mathrm{T}}$ & 36 & Lys-Ala & - & + & + & - & - & - & - \\
\hline S. oralis & NCTC $11427^{\mathrm{T}}$ & 37 & Lys-direct & + & $(+)$ & $(+)$ & + & $(+)$ & + & + \\
\hline S. pneumoniae & DSM $20566^{\mathrm{T}}$ & 36 & Lys-Ala 2 (Ser) & + & - & + & + & - & + & + \\
\hline S. pneumoniae & $\mathbf{R} \boldsymbol{\sigma}^{f}$ & 38 & Lys-Ala $($ Ser) & + & - & + & - & - & + & + \\
\hline S. pneumoniae & Curif & 37 & Lys-Ala $($ Ser) & + & - & + & - & - & + & + \\
\hline S. pyogenes & NCTC $8198^{\mathrm{T}}$ & 38 & Lys-Ala $_{1-3}$ & - & + & - & - & + & - & ND \\
\hline S. rattus & ATCC $19645^{\mathrm{T}}$ & 40 & Lys-Ala ${ }_{2-3}$ & - & + & - & + & ND & ND & ND \\
\hline S. salivarius & DSM $20560^{\mathrm{T}}$ & 39 & Lys-Ala & - & + & + & + & - & + & - \\
\hline S. sanguis I & ATCC $10556^{\mathrm{T}}$ & 43 & Lys-Ala $1-3$ & - & + & + & - & + & - & - \\
\hline S. sanguis I & Kiel 12700 & 43 & Lys-Ala ${ }_{1-3}$ & - & + & + & - & + & - & - \\
\hline$S$. sanguis I group $\mathrm{H}$ & Kiel 75360 & ND & Lys-Ala & - & + & + & + & + & - & - \\
\hline S. sanguis II & DSM 20066 & 39 & Lys-direct & + & $(+)$ & + & + & - & + & + \\
\hline S. sanguis II & Kiel 61162 & 38 & Lys-direct & + & - & $(+)$ & + & + & + & + \\
\hline S. sobrinus & ATCC $33478^{\mathrm{T}}$ & 43 & Lys-Thr-Ala & - & + & + & + & ND & ND & ND \\
\hline S. uberis & NCTC $3858^{\mathrm{T}}$ & ND & Lys-Ala $_{1-3}$ & - & + & + & - & + & - & - \\
\hline "S. viridans" I & Kiel 50493 & 38 & Lys-direct & + & - & + & + & - & + & + \\
\hline "S. viridans" II & Kiel 60973 & 38 & Lys-direct & + & - & + & + & + & + & + \\
\hline “'S. viridans" III & Kiel 45527 & 36 & Lys-direct & - & + & + & + & $(+)$ & + & - \\
\hline “S, viridans" IV & Kiel 42841 & 38 & Lys-direct & + & - & - & + & + & $(+)$ & + \\
\hline Streptococcus sp. group O & Kiel C119/48 & 39 & Lys-direct & + & - & + & + & + & $(+)$ & + \\
\hline $\begin{array}{l}\text { Streptococcus sp. (" } S \text {. } \\
\text { mitior"-S. sanguis) }\end{array}$ & $\mathrm{S} 229^{g}$ & 40 & Lys-direct & + & $(+)$ & $(+)$ & + & + & + & + \\
\hline $\begin{array}{l}\text { Streptococcus } \mathrm{sp.} \\
\quad(" S . \text { mitior"-S. sanguis) }\end{array}$ & $\mathrm{S} 410^{g}$ & 40 & Lys-direct & + & - & $(+)$ & + & + & $(+)$ & + \\
\hline $\begin{array}{l}\text { Streptococcus } \mathrm{sp} . \\
\quad \text { ("S. mitior"-S. sanguis) }\end{array}$ & $\mathrm{S} 426^{g}$ & 39 & Lys-direct & + & - & - & + & - & + & + \\
\hline $\begin{array}{l}\text { Streptococcus sp. } \\
\text { ("S. mitior"'-S. sanguis) }\end{array}$ & $\mathrm{S} 438^{\circ}$ & 40 & Lys-direct & + & - & + & + & + & $(+)$ & + \\
\hline $\begin{array}{l}\text { Streptococcus } \mathrm{sp} . \\
\quad \text { ("S. mitior"-S. sanguis) }\end{array}$ & $\mathrm{S} 440^{g}$ & 40 & Lys-sirect & + & - & - & + & + & + & + \\
\hline $\begin{array}{l}\text { Streptococcus sp. } \\
\quad \text { ("S. mitior"-S. sanguis) }\end{array}$ & $\mathrm{S} 444^{g}$ & 40 & Lys-direct & + & $(+)$ & + & + & + & + & + \\
\hline $\begin{array}{l}\text { Streptococcus sp. } \\
\text { ("S. mitior"-S. sanguis) }\end{array}$ & $\mathrm{S} 447^{\circ}$ & 39 & Lys-direct & + & $(+)$ & $(+)$ & + & - & + & + \\
\hline $\begin{array}{l}\text { Streptococcus sp. } \\
\quad \text { ("S. mitior"-S. sanguis) }\end{array}$ & $\mathrm{S} 526^{g}$ & 39 & Lys-direct & + & $(+)$ & $(+)$ & + & - & + & + \\
\hline $\begin{array}{l}\text { Streptococcus sp. } \\
\quad \text { ("S. mitior"-S. sanguis) }\end{array}$ & $\mathrm{S} 662^{g}$ & 39 & Lys-direct & + & - & - & + & $(+)$ & + & + \\
\hline Enterococcus faecalis & DSM $20478^{\mathrm{T} g}$ & 39 & Lys-Ala $2-3$ & + & + & + & + & + & + & - \\
\hline Staphylococcus aureus & $\operatorname{ATCC} 12600^{\mathrm{T}}$ & $35^{h}$ & Lys-Gly ${ }_{5-6}$ & + & - & - & - & + & - & - \\
\hline
\end{tabular}

a NCDO, National Collection of Dairy Organisms. Shinfield, Reading, United Kingdom; DSM, Deutsche Sammlung von Mikroorganismen, Göttingen, Federal Republic of Germany; ATCC, American Type Culture Collection, Rockville, Md.; NCTC, National Collection of Type Cultures, Central Public Health Laboratory, London, England; Kiel, Streptokokkenzentrale, Kiel, Federal Republic of Germany.

$b_{-}$, Absent; + , present; $(+)$, present in minor amounts.

${ }^{c} \mathrm{GlcNH}_{2}$, Glucosamine.

${ }^{d} \mathrm{GalNH}_{2}$, Galactosamine.

e ND, Not determined.

${ }^{f}$ Received from R. Hakenbeck, Max-Planck-Institut für Molekulare Genetik, Berlin, Federal Republic of Germany.

${ }^{g}$ Received from F. Gehring, Lehrstuhl Experimentale Zahnheilkunde, Würzburg, Federal Republic of Germany.

${ }^{n}$ From reference 20. 
teichoic acid and choline in their cell walls distinguished the viridans streptococci from group-R and $-\mathrm{S}$ streptococci that also possessed the Lys-direct peptidoglycan type but lacked ribitol and choline in their cell walls (Table 1). The ribitolcontaining polymer of $S$. oralis NCTC $11427^{\mathrm{T}}$ was studied in more detail. Cell wall hydrolysates ( $2 \mathrm{M} \mathrm{HCl}, 3 \mathrm{~h}, 100^{\circ} \mathrm{C}$ ) showed that ribitol and phosphorus were present in about equimolar amounts. Only very low amounts of ribitol were released from cell walls by treatment with $70 \%$ hydrofluoric acid at $0^{\circ} \mathrm{C}$ for $3 \mathrm{~h}$, and maximum yields were obtained only after acid hydrolysis of the hydrofluoric acid degradation products. Ribitol and sugars were simultaneously released, indicating the presence of ribitol teichoic acid. Galactose and galactosamine were found as major sugar constituents. Minor amounts of glucose and rhamnose also were present. The cell wall of $S$. oralis NCTC $11427^{\mathrm{T}}$ was extracted with $60 \%$ hydrofluoric acid for $16 \mathrm{~h}$ at $0^{\circ} \mathrm{C}$. Released glycosides were separated on a Bio-Gel P2 column and analyzed as previously described (9). An oligomer consisting of equimolar amounts of ribitol, galactose, and galactosamine was identified.

"S. viridans" III Kiel 45527 differed from the other viridans streptococci in that it lacked ribitol teichoic acid and choline and, in this respect, resembled group- $\mathrm{R}$ and $-\mathrm{S}$ streptococci.

Choline does not seem to be as good a criterion for the identification of $S$. oralis as ribitol teichoic acid, since choline also was found in some strains of $S$. constellatus (unpublished results). Cell walls of viridans streptococci can also contain rhamnose polysaccharides, but in significantly smaller amounts than are usually found in cell walls of streptococci.

The moles percent $\mathrm{G}+\mathrm{C}$ contents are also shown in Table 1. Significantly different values were found only for $S$. sanguis I strains. Such high $\mathrm{G}+\mathrm{C}$ contents (43 mol\%) are, with the exception of $S$. sobrinus, rather unusual for streptococci. The moles percent $\mathrm{G}+\mathrm{C}$ contents of the mutanslike streptococci (see Tables 1 and 5) were corrected with the value for $E$. coli $\mathrm{K}-12$, as was done for all the other strains studied. For that reason they differ slightly from the values in a former publication (29).

Nucleic acid hybridization studies. The results of DNAribosomal ribonucleic acid hybridization studies (Table 2) showed that most of the oral streptococci formed a group of related species with differences in the melting point between homologous and heterologous hybrids $\left[\Delta T_{m(e)}\right]$ of $<4^{\circ} \mathrm{C}$. The closer relationship of " $S$. viridans" strains to $S$. sanguis II than to $S$. sanguis I was indicated by $\Delta T_{m(e)}$ values below $1.0^{\circ} \mathrm{C}$. Some organisms, such as $S$. acidominimus and $S$. salivarius, which were also classified as viridans streptococci by different authors $(3,10-12,24,25)$, had $\Delta T_{m(e)}$ values above $4^{\circ} \mathrm{C}$, idicating no close genetic relationship with either $S$. sanguis I or S. sanguis II. Similar results were found for " $S$. viridans" III (Table 2). Moreover, the rather high $\Delta T_{m(e)}$ value of $8.6^{\circ} \mathrm{C}$ for $S$. morbillorum is in the range of those for Enterococcus faecalis $(28)$ and $S$. lactis $(\mathrm{K} . \mathrm{H}$. Schleifer, J. Kraus, C. Dvorak, R. Kilpper-Bälz, M. D. Collins, and W. Fischer, Syst. Appl. Microbiol, in press). Further studies are necessary to show whether $S$. morbillorum should be excluded from the genus Streptococcus, as was proposed for $S$. lactis and related organisms (Schleifer et al., in press).

DNA-DNA hybridization studies were carried out to obtain information about the genetic relationships within the true viridans streptococci. Table 3 shows a group with very high DNA homology values consisting of $S$. oralis, $S$.
TABLE 2. Results of DNA-ribosomal ribonucleic acid hybridization studies

\begin{tabular}{|c|c|c|c|c|}
\hline \multirow{3}{*}{ Source of DNA } & \multicolumn{4}{|c|}{ Labeled $23 \mathrm{~S}$ ribosomal ribonucleic acid from: } \\
\hline & \multicolumn{2}{|c|}{ S. sanguis I ATCC $10556^{\mathrm{T}}$} & \multicolumn{2}{|c|}{$\begin{array}{l}\text { S. sanguis II DSM } \\
20066\end{array}$} \\
\hline & $T_{m(e)}{ }^{a}$ & $\overline{\Delta T_{m(e)}}$ & $T_{m(e)}{ }^{a}$ & $\Delta T_{m(e)}$ \\
\hline $\begin{array}{l}\text { S. sanguis I } \\
\text { ATCC } 10556^{\mathrm{T}}\end{array}$ & 78.0 & 0.0 & 75.7 & 2.6 \\
\hline $\begin{array}{l}\text { S. sanguis I } \\
\text { Kiel } 75360\end{array}$ & 77.6 & 0.4 & & \\
\hline $\begin{array}{l}\text { "S. viridans" IV } \\
\text { Kiel } 42841\end{array}$ & 75.8 & 2.2 & 77.5 & 0.8 \\
\hline $\begin{array}{l}\text { S. constellatus } \\
\text { DSM } 20575^{\mathrm{T}}\end{array}$ & 74.9 & 3.1 & & \\
\hline $\begin{array}{l}\text { "S. viridans" I } \\
\text { Kiel } 50493\end{array}$ & 74.9 & 3.1 & 77.6 & 0.7 \\
\hline $\begin{array}{l}\text { S. mitis DSM } \\
20568^{\mathrm{T}}\end{array}$ & 74.8 & 3.2 & & \\
\hline $\begin{array}{l}\text { S. sanguis II } \\
\text { DSM } 20066\end{array}$ & 74.5 & 3.5 & 78.3 & 0.0 \\
\hline $\begin{array}{l}\text { S. mutans } \\
\text { ATCC } 25175^{\mathrm{T}}\end{array}$ & 74.2 & 3.8 & 75.3 & 3.0 \\
\hline $\begin{array}{l}\text { S. iniae DSM } \\
20576^{\mathrm{T}}\end{array}$ & 74.2 & 3.8 & & \\
\hline $\begin{array}{l}\text { S. bovis DSM } \\
20480^{\mathrm{T}}\end{array}$ & 74.0 & 4.0 & & \\
\hline $\begin{array}{l}\text { "S. viridans"' III } \\
\text { Kiel } 45527\end{array}$ & 74.0 & 4.0 & 73.8 & 4.5 \\
\hline $\begin{array}{l}S . \text { cricetus } \\
\text { ATCC } 19642^{\mathrm{T}}\end{array}$ & 73.5 & 4.5 & & \\
\hline $\begin{array}{l}\text { S. salivarius } \\
\text { DSM } 20560^{\mathrm{T}}\end{array}$ & 73.0 & 5.0 & & \\
\hline $\begin{array}{l}\text { S. acidominimus } \\
\text { NCDO } 2025^{\mathrm{T}}\end{array}$ & 72.5 & 5.5 & & \\
\hline $\begin{array}{l}\text { S. morbillorum } \\
\text { DSM } 20572^{\mathrm{T}}\end{array}$ & 69.4 & 8.6 & & \\
\hline $\begin{array}{l}\text { E. faecalis DSM } \\
20478^{\mathrm{T}}\end{array}$ & 68.3 & 9.7 & & \\
\hline $\begin{array}{l}\text { S. lactis DSM } \\
20481^{\mathrm{T}}\end{array}$ & 68.3 & 9.7 & & \\
\hline $\begin{array}{l}\text { S. aureus ATCC } \\
12600^{\mathrm{T}}\end{array}$ & 67.5 & 10.5 & 69.1 & 9.2 \\
\hline
\end{tabular}

${ }^{a}$ Temperatures at $50 \%$ of the bound rRNA was eluted from the hybrids.

sanguis II, "S. viridans" I and II, and " $S$. mitior"- $S$. sanguis strains. The high homology values indicated a relationship at the species level, which is in accord with the results of the cell wall analysis and physiological data (see Tables 1 and 4). Three strains ("S. viridans" II Kiel 60973 and "S. mitior"'-S. sanguis S526 and S662) hybridized slightly less with the other strains of this group, but additional hybridization studies with stringent conditions again revealed high homology values $(>70 \%)$. This result indicates that these strains should also be classified as the same species.

On the average, there was still a high degree of homology $(56 \%)$ between $S$. oralis and $S$. pneumoniae as well as between group-O Streptococcus spp. and " $S$. viridans" IV. However, DNA homology values below $70 \%$ justify a separate species status (31). This is obvious in the case of $S$. pneumoniae, but it is not possible to classify the other two organisms as a separate species until more strains have been studied.

All the viridans streptococci shared slightly higher DNA homology $(25 \%)$ with some of the other oral streptococci, such as $S$. anginosus, $S$. constellatus, $S$. intermedius, $S$. mitis, and $S$. sanguis I, than with others (Table 3 ). They may 
TABLE 3. DNA homology values of various oral streptococci ${ }^{a}$

\begin{tabular}{|c|c|c|c|c|c|c|c|c|c|c|c|c|c|}
\hline \multirow[b]{2}{*}{ Source of filter-bound DNA } & \multicolumn{13}{|c|}{ \% Homology with labeled DNA from: } \\
\hline & 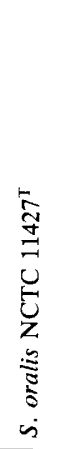 & 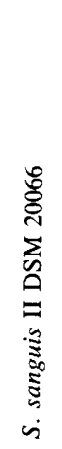 & 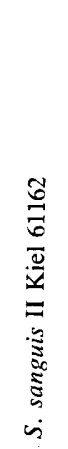 & 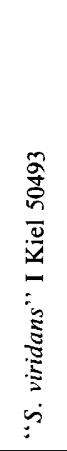 & 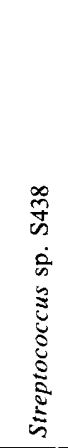 & 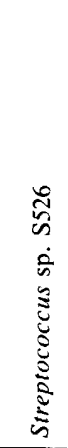 & 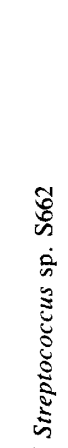 & 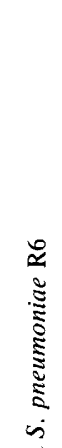 & 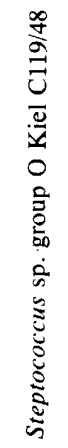 & 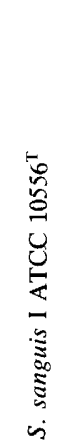 & 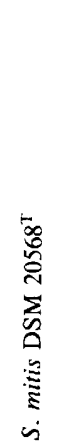 & 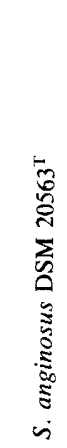 & 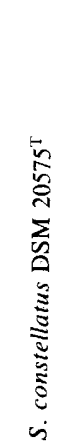 \\
\hline S. oralis NCTC $11427^{\mathrm{T}}$ & 100 & 92 & 72 & 84 & 98 & 98 & 82 & 44 & 60 & & & 19 & 18 \\
\hline S. sanguis II DSM 20066 & & 100 & 98 & 97 & 100 & 100 & & 51 & & & & & \\
\hline S. sanguis II Kiel 61162 & & 80 & 100 & 100 & & & & & & & & & \\
\hline "S, viridans" I Kiel 50493 & 91 & 84 & 74 & 100 & 86 & 92 & 75 & 48 & 60 & & & & \\
\hline Streptococcus sp. S229 & & 100 & & & 75 & 85 & & & & & & & \\
\hline Streptococcus sp. S410 & & 82 & & & 81 & 83 & & & & & & & \\
\hline Streptococcus sp. S426 & & 72 & & & 83 & 89 & & & & & & & \\
\hline Streptococcus sp. S438 & & 80 & & & 100 & 100 & & & & & & & \\
\hline Streptococcus sp. S440 & 100 & 87 & & & 100 & 92 & 86 & & 66 & & & & \\
\hline Streptococcus sp. S444 & & & & & 74 & 95 & & & & & & & \\
\hline Streptococcus sp. S447 & & 78 & & & 86 & 100 & & & & & & & \\
\hline Streptococcus sp. S526 & 74 & 79 & & & 76 & 100 & 72 & & 59 & & & & \\
\hline Streptococcus sp. S662 & 75 & 75 & & & 72 & 76 & 100 & & 59 & & & & \\
\hline "S. viridans" II Kiel 60973 & & 77 & 60 & 75 & & & & 43 & & & & & \\
\hline “S. viridans" IV Kiel 42841 & 42 & 58 & 54 & 57 & 42 & 41 & 43 & 43 & 42 & & & 22 & \\
\hline S. pneumoniae DSM $20566^{\mathrm{T}}$ & & & & & & & & 90 & & & & & \\
\hline S. pneumoniae $\mathbf{R 6}$ & 53 & 62 & 50 & 68 & & 50 & 50 & 100 & 65 & & & 18 & 17 \\
\hline S. pneumoniae Curi & & & & & & & & \begin{tabular}{|l|}
92 \\
\end{tabular} & & & & & \\
\hline Streptococcus sp. group O & 58 & & & & & 57 & 56 & & 100 & & & & \\
\hline S. sanguis I ATCC $10556^{\mathrm{T}}$ & 26 & 29 & 30 & & 26 & 23 & 21 & & 22 & 100 & 45 & 25 & 23 \\
\hline S. sanguis I Kiel 12700 & & 25 & 26 & 29 & & & & & & 79 & 41 & 22 & 20 \\
\hline S. sanguis I Kiel 75360 & & & 31 & & & & & & & 77 & & 26 & \\
\hline S. mitis DSM $20568^{\mathrm{T}}$ & & & 38 & & & & & & & 41 & & 29 & 27 \\
\hline$S$, anginosus DSM $20563^{\mathrm{T}}$ & & & & & & & & & & & & 100 & 57 \\
\hline S. constellatus DSM $20575^{\mathrm{T}}$ & & & & & & & & & & & & 66 & 100 \\
\hline S. intermedius DSM $20573^{\mathrm{T}}$ & & & & & & & & & & & & 55 & 62 \\
\hline "S. viridans" III Kiel 45527 & 20 & 18 & 19 & & 17 & 20 & & & 18 & & & & \\
\hline S. salivarius DSM $20560^{\mathrm{T}}$ & & 16 & 15 & & & & & & & & & & \\
\hline S. mutans ATCC $25175^{\mathrm{T}}$ & & 18 & 15 & 21 & & & & & & & & 17 & 17 \\
\hline S. pyogenes NCTC $8198^{\mathrm{T}}$ & 17 & 18 & 16 & & & 15 & 13 & & 15 & & & & \\
\hline E. faecalis DSM $20478^{\mathrm{T}}$ & & 8 & 7 & 8 & & & & & & & & 8 & \\
\hline
\end{tabular}

${ }^{a}$ The values were determined under optimal hybridization conditions $\left(25^{\circ} \mathrm{C}\right.$ below the melting temperature of DNA). Boxed values indicate relatedness at the species level.

be considered to be members of a species group within the streptococci similar to certain species groups within the staphylococci (30). " $S$. viridans" III was the only exception among the viridans streptococci, since it did not have a close genetic relationship with the other viridans streptococci. However, this strain also differed from the typical viridans streptococci by the lack of ribitol teichoic acid and choline in its cell wall.

$S$. sanguis I and $S$. mitis, which contained a peptidoglycan of the Lys-Ala ${ }_{1-3}$ type, also were genetically different from the $S$. oralis- $S$. pneumoniae-" $S$. viridans" group (DNA homology values $\approx 25 \%$ ). The DNA homology value of $40 \%$ for $S$. sanguis I and $S$. mitis indicates that their classification as different species is justified. However, more strains should be investigated to find suitable differentiating characteristics for these two species. The genetic diversity of $S$. sanguis I, S. sanguis II, and S. mitis (Table 3) is in good agreement with the data reported by Coykendall and Specht (6) and Welborn et al. (36).

Physiological differentiation. Physiological tests were carried out with the genetically well-defined strains to find reliable differentiating characteristics for these species (Table 4). The results were generally in accord with those of other studies. $S$. oralis was the only validly described species within the group of strains that were genetically and physiologically highly related; therefore, they should be regarded as members of the same species. Differential characteristics for the routine identification of $S$. oralis in laboratories are shown in Table 5 . The most characteristic feature of $S$. oralis is, besides the unique cell wall composition, the inability to hydrolyze esculin or produce acid from inulin. The physiological tests were usually sufficient to distinguish $S$. oralis from other oral streptococci. However, in a few cases, such as " $S$. viridans" I Kiel 50493 and $S$. 
TABLE 4. Physiological reactions of viridans streptococci ${ }^{a}$

\begin{tabular}{|c|c|c|c|c|c|c|c|c|c|c|c|}
\hline \multirow{2}{*}{ Strain } & \multirow{2}{*}{$\begin{array}{l}\text { Acetoin } \\
\text { produc- } \\
\text { tion }\end{array}$} & \multirow{2}{*}{$\begin{array}{l}\text { Esculin } \\
\text { hydro- } \\
\text { lysis }\end{array}$} & \multirow{2}{*}{$\begin{array}{c}\text { Arginin } \\
\text { hydro- } \\
\text { lysis }\end{array}$} & \multicolumn{8}{|c|}{ Acid production from: } \\
\hline & & & & Salicin & Inulin & Sorbitol & Mannitol & Cellobiose & Trehalose & Ribose & Raffinose \\
\hline S. oralis NCTC $11427^{\mathrm{T}}$ & + & - & + & + & - & - & - & - & + & + & - \\
\hline S. sanguis II DSM 20066 & + & + & + & + & - & - & + & + & + & + & + \\
\hline S. sanguis II Kiel 61162 & + & - & - & - & - & - & - & - & - & - & + \\
\hline "S. viridans" I Kiel 50493 & + & + & + & + & + & - & + & + & + & + & + \\
\hline Streptococcus sp. S229 & + & - & - & + & - & - & - & - & - & ND & + \\
\hline Streptococcus sp. S410 & + & - & - & - & - & - & - & - & - & ND & + \\
\hline Streptococcus sp. S426 & $(+)$ & - & - & - & - & - & - & - & - & ND & - \\
\hline Streptococcus sp. S438 & + & - & - & + & - & - & - & - & - & ND & + \\
\hline Streptococcus sp. S440 & + & - & - & - & - & - & - & - & + & ND & + \\
\hline Streptococcus sp. S444 & + & - & - & - & - & - & - & - & - & ND & + \\
\hline Streptococcus sp. S447 & + & - & - & - & - & - & - & + & + & ND & + \\
\hline Streptococcus sp. S526 & + & - & - & - & - & - & - & - & - & ND & - \\
\hline Streptococcus sp. S662 & $(+)$ & - & - & - & - & - & - & - & - & ND & + \\
\hline "S. viridans" II Kiel 60973 & + & - & + & - & - & - & - & - & - & - & + \\
\hline S. pneumoniae DSM $20566^{\mathrm{T}}$ & - & + & + & - & - & - & - & - & + & - & + \\
\hline S. pneumoniae R6 & ND & + & - & ND & - & ND & ND & ND & ND & ND & ND \\
\hline S. pneumoniae Curi & ND & + & - & ND & - & ND & ND & ND & ND & ND & ND \\
\hline $\begin{array}{l}\text { Streptococcus sp. group O } \\
\text { Kiel C } 119 / 48\end{array}$ & $(+)$ & - & - & + & - & - & - & + & - & - & - \\
\hline "S. viridans" IV Kiel 42841 & - & - & - & - & - & - & - & - & - & - & - \\
\hline S. sanguis I ATCC $10556^{\mathrm{T}}$ & - & + & - & - & + & - & - & - & + & - & - \\
\hline S. sanguis I Kiel 75360 & - & - & - & + & + & - & - & + & + & - & - \\
\hline S. mitis DSM $20568^{\mathrm{T}}$ & $(+)$ & + & + & + & + & - & - & + & + & + & + \\
\hline S. anginosus DSM $20563^{\mathrm{T}}$ & + & + & + & + & - & - & - & + & + & - & + \\
\hline S. constellatus DSM $20575^{\mathrm{T}}$ & + & + & + & + & - & - & - & - & + & - & + \\
\hline S. intermedius DSM $20573^{\mathrm{T}}$ & - & + & + & + & - & - & - & + & + & - & + \\
\hline "S. viridans" III Kiel 45527 & - & + & - & - & + & - & - & + & + & - & - \\
\hline S. salivarius DSM $20560^{\mathrm{T}}$ & + & + & - & + & + & - & - & ND & ND & ND & + \\
\hline S. mutans ATCC $25175^{\mathrm{T}}$ & - & + & - & + & + & + & + & + & + & - & + \\
\hline S. uberis NCTC $3858^{\mathrm{T}}$ & + & + & + & + & + & + & + & + & + & + & - \\
\hline S. acidominimus NCDO $2025^{\mathrm{T}}$ & + & + & + & + & + & + & + & + & + & + & + \\
\hline S. pyogenes NCTC $8198^{\mathrm{T}}$ & $(+)$ & + & - & + & - & - & - & ND & + & - & - \\
\hline
\end{tabular}

$a_{+}+$, Positive; $(+)$, weakly positive; - , negative; ND, not determined.

sanguis II DSM 20066, cell wall analysis was necessary to classify them as $S$. oralis. Based on the emended description of $S$. oralis, many strains previously designated as $S$. sanguis II, "S. viridans" I and II, and " $S$. mitior" should be transferred to $S$. oralis. $S$. mitis, on the other hand, which is often confused with " $S$. mitior," has a separate species status and can be separated from $S$. oralis on the basis of the characteristics shown in Table 5.

TABLE 5. Differentiating characteristics of oral streptococci ${ }^{a}$

\begin{tabular}{|c|c|c|c|c|c|c|c|c|c|c|c|c|c|}
\hline \multirow[b]{2}{*}{ Organism (no. tested) } & \multirow[b]{2}{*}{ Murein type } & \multirow[b]{2}{*}{$\begin{array}{l}\text { Cell wall } \\
\text { teichoic } \\
\text { acid }\end{array}$} & \multirow[b]{2}{*}{$\begin{array}{c}\text { Choline } \\
\text { in cell } \\
\text { walls }\end{array}$} & \multirow[b]{2}{*}{$\begin{array}{c}\mathrm{G}+\mathrm{C} \\
\text { content } \\
(\mathrm{mol} \%)\end{array}$} & \multicolumn{2}{|c|}{ Production of: } & \multirow[b]{2}{*}{$\begin{array}{l}\text { Hydro- } \\
\text { lysis of } \\
\text { esculin }\end{array}$} & \multicolumn{6}{|c|}{ Acid production from: } \\
\hline & & & & & $\begin{array}{l}\text { Acet- } \\
\text { oin }\end{array}$ & $\begin{array}{l}\mathrm{NH}_{3} \\
\text { from } \\
\text { argi- } \\
\text { nine }\end{array}$ & & $\begin{array}{c}\text { Sali- } \\
\text { cin }\end{array}$ & Inulin & $\begin{array}{l}\text { Man- } \\
\text { nitol }\end{array}$ & $\begin{array}{c}\text { Sorbi- } \\
\text { tol }\end{array}$ & $\begin{array}{c}\text { Treha- } \\
\text { lose }\end{array}$ & $\begin{array}{c}\text { Raffi- } \\
\text { nose }\end{array}$ \\
\hline S. oralis (14) & Lys-direct & Ribitol & + & $37-40$ & + & $(-)$ & - & $\mathrm{v}$ & - & - & - & $\mathrm{v}$ & $(+)$ \\
\hline S. pneumoniae (3) & Lys-Ala 2 (Ser) & Ribitol & + & $36-37$ & - & $\mathrm{v}$ & + & - & - & - & - & + & + \\
\hline S. sanguis (2) & Lys-Ala $_{1-3}$ & & - & 43 & - & - & $\mathrm{v}$ & $\mathrm{v}$ & + & - & - & + & - \\
\hline S. mitis (1) & Lys-Ala & & - & 38 & + & + & + & + & + & - & - & + & + \\
\hline S. anginosus (5) & Lys-Ala & & $\mathrm{v}$ & $37-39$ & + & + & + & + & - & - & - & + & - \\
\hline S. constellatus $(6)$ & Lys-Ala & & $\mathrm{v}$ & $36-37$ & + & + & + & + & - & - & - & + & - \\
\hline S. intermedius (1) & Lys-Ala ${ }_{1-3}$ & & - & 37 & - & + & + & + & - & - & - & + & + \\
\hline S. salivarius (3) & Lys-Ala & & - & 39 & + & $\mathrm{v}$ & + & + & + & - & - & $\mathrm{v}$ & + \\
\hline S. mutans $(6)^{b}$ & Lys-Ala ${ }_{1-3}$ & & - & $35-36$ & - & - & + & + & + & + & + & + & + \\
\hline S. cricetus $(4)^{b}$ & Lys-Thr-Ala & & - & $40-41$ & + & - & ND & - & + & - & - & + & + \\
\hline S. sobrinus $(4)^{b}$ & Lys-Thr-Ala & & ND & $41-43$ & - & - & - & - & + & + & + & + & - \\
\hline S. ferus (1) & Lys-Ala $2-3$ & & ND & 42 & + & - & + & + & + & + & + & - & - \\
\hline S. rattus $(4)^{b}$ & Lys-Ala $2-3$ & Glycerol & ND & $40-41$ & - & + & + & + & + & + & + & - & + \\
\hline S. uberis (1) & Lys-Ala ${ }_{1-3}$ & & - & ND & + & + & + & + & + & + & + & + & - \\
\hline S. acidominimus (1) & ND & & - & ND & + & + & + & + & + & + & + & + & + \\
\hline
\end{tabular}

$a+$, More than $80 \%$ positive; - , more than $80 \%$ negative; $v$, variable; $(+)$, more than $70 \%$ positive; $(-)$, more than $70 \%$ negative; ND, not determined.

${ }^{b}$ The physiolocal reactions of this species were only studied for the type strain. 
The following emended description of $S$. oralis is based on the description given by Bridge and Sneath (1) and our results.

Cells are gram-positive cocci in short chains and have no capsules. They are nonmotile, nonsporeforming, aerobic, facultatively anaerobic, fermentative, and catalase negative. They are hemolytic on horse blood agar and produce pronounced greening (alpha hemolytic). They reduce $0.1 \%$ tetrazolium and nitrite and decarboxylate lysine. They grow with $0.0004 \%$ crystal violet but not with $3 \%$ sodium chloride. The Voges-Proskauer reaction is positive. The methyl red reaction, growth with sodium azide, and dextran production are variable. Gluconate is usually not oxidized. More than $80 \%$ produce acid from ribose, $N$-acetylglucosamine, lactose, and sucrose. Acid production from glycerol, salicin, D-(+)-melibiose, D-(-)-trehalose, D- $(+)$-melezitose, D- $(+)$ raffinose, dextrin, meso-inositol, arbutin, D- $(+)$ cellobiose, starch, and glycogen is variable. Less than $20 \%$ produce acid from erythritol, D-(-)-arabinose, D- $(+)$-arabinose, amygdalin, L-(-)-sorbose, rhamnose, mannitol, sorbitol, and inulin. Tetrathionate reductase is usually produced, lipase production is variable, and deoxyribonuclease production is negative. There is usually no hydrolysis of esculin or production of ammonia from arginine. The $\mathrm{G}+\mathrm{C}$ content is 37.6 to $40.5 \mathrm{~mol} \%$. The cell walls contain a peptidoglycan of the Lys-direct type, ribitol cell wall teichoic acid, and choline. Galactose or glucose or both and galactosamine or glucosamine or both are present as major sugar constituents. Rhamnose is absent or present only in minor amounts. The habitat is the human mouth. The type strain is NCTC 11427.

\section{ACKNOWLEDGMENTS}

This work was supported by the Gesellschaft für Biotechnologische Forschung for performing research of relevance for the German Collection of Microorganisms and by a grant from the Deutsche Forschungsgemeinschaft.

We thank F. Fiedler for the information that choline may be present in cell walls of oral streptococci. We thank Ingrid Pomper and Ingrid Högner for excellent technical assistance.

\section{LITERATURE CITED}

1. Bridge, P. D., and P. H. A. Sneath. 1982. Streptococcus gallinarum sp. nov. and Streptococcus oralis sp. nov. Int. J. Syst. Bacteriol. 32:410-415.

2. Bucher, C., and A. von Graevenitz. 1984. Differentiation in throat cultures of group C and G streptococci from Streptococcus milleri with identical antigens. Eur. J. Clin. Microbiol. 3:44-45.

3. Colman, G., and R. E. O. Williams. 1972. Taxonomy of some human viridans streptococci, p. 281-299. In L. W. Wannamaker and J. M. Matsen (ed.), Streptococci and streptococcal diseases. Academic Press, Inc., New York.

4. Coykendall, A. L. 1977. Proposal to elevate the subspecies of Streptococcus mutans to species status, based on their molecular composition. Int. J. Syst. Bacteriol. 27:26-30.

5. Coykendall, A. L. 1983. Streptococcus sobrinus nom. rev. and Streptococcus ferus nom, rev.: habitat of these and other mutans streptococci. Int. J. Syst. Bacteriol. 33:883-885.

6. Coykendall, A. L., and P. A. Specht. 1975. DNA base sequence homologies among strains of Streptococcus sanguis. J. Gen. Microbiol. 91:92-98.

7. De Ley, J. 1970. Reexamination of the association between melting point, buoyant density, and chemical base composition of deoxyribonucleic acid. J. Bacteriol. 101:738-754.

8. Durack, D. T., and R. G. Petersdorf. 1977. Changes in the epidemiology of endocarditis, p. 3-7. In E. L. Kaplan and A. V. Taranta (ed.), Infective endocarditis-an American Heart Association Symposium. American Heart Association, Dallas.
9. Endl, J., P. H. Seidl, F. Fiedler, and K. H. Schleifer. 1983. Chemical composition and structure of cell wall teichoic acids of staphylococci. Arch. Microbiol. 135:215-223.

10. Facklam, R. R. 1977. Physiological differentiation of viridans streptococci. J. Clin. Microbiol. 5:184-201.

11. Facklam, R. R., and H. W. Wilkinson. 1981. The family Streptococcaceae (medical aspects), p. 1572-1597. In M. P. Starr, H. Stolp, H. G. Trüper, A. Balows, and H. G. Schlegel (ed.), The procaryotes, vol. 2. Springer-Verlag KG, Berlin.

12. Hardie, J. M., and G. H. Bowden. 1976. Physiological classification of oral viridans streptococci. J. Dent. Res. 55: A166-A176.

13. Hardie, J. M., and P. D. Marsh. 1978. Streptococci and the human oral flora, p. 157-206. In F. A. Skinner and L. B. Quesnel (ed.), Streptococci. Academic Press, Inc. (London), Ltd., London.

14. Hardie, J. M., R. A. Whiley, and M. J. Sackin. 1981. A numerical taxonomic study of oral streptococci, p. 59-60. In S. E. Holm and P. Christensen (ed.), Basic concepts of streptococci and streptococcal diseases. Reed Books I.td., Surrey, England.

15. Horstmeier, C., and J. A. Washington II. 1973. Microbiological study of streptococcal bacteremia. Appl. Microbiol. 26:589-591.

16. Huss, V. A. R., H. Festl, and K. H. Schleifer. 1983. Studies on the spectrophotometric determination of DNA hybridization from renaturation rates. Syst. Appl. Microbiol. 4:184-192.

17. Jones, D. 1978. Composition and differentiation of the genus Streptococcus, p. 1-49. In F. A. Skinner and L. B. Quesnel (ed.), Streptococci. Academic Press, Inc. (London), Ltd., London.

18. Kaye, D. 1976. Infecting microorganisms, p. 46-47. In D. Kaye (ed.), Infective endocarditis. University Park Press, Baltimore.

19. Kilpper, R., U. Buhl, and K. H. Schleifer. 1980. Nucleic acid homology studies between Peptococcus saccharolyticus and various anaerobic and facultatively anaerobic gram-positive cocci. FEMS Microbiol. Lett. 8:205-210.

20. Kilpper-Bälz, R., and K. H. Schleifer. 1981. DNA-rRNA hybridization studies among staphylococci and some other grampositive bacteria. FEMS Microbiol. Lett. 10:357-362.

21. Kilpper-Bälz, R., and K. H. Schleifer. 1984. Nucleic acid hybridization and cell wall composition studies of pyogenic streptococci. FEMS Microbiol. Lett. 24:355-364.

22. Kilpper-Bälz, R., B. L. Williams, R. Lütticken, and K. H. Schleifer. 1984. Relatedness of "Streptococcus milleri" with Streptococcus anginosus and Streptococcus constellatus. Syst. Appl. Microbiol. 5:494-500.

23. Parker, M. T., and L. C. Ball. 1976. Streptococci and aerococci associated with systemic infection in man. J. Med. Microbiol. 9:275-302.

24. Ruoff, K. L., and L. J. Kunz. 1982. Identification of viridans streptococci isolated from clinical specimens. J. Clin. Microbiol. 15:920-925.

25. Ruoff, K. L., and L. J. Kunz. 1983. Use of the rapid STREP system for identification of viridans steptococcal species. J. Clin. Microbiol. 18:1138-1140.

26. Schleifer, K. H., and O. Kandler. 1967. Zur chemischen Zusammensetzung der Zellwand der Streptokokken. I. Die Aminosäuresequenz des Mureins von Streptococcus thermophilus und Streptococcus faecalis. Arch. Mikrobiol. 57:335-364.

27. Schleifer, K. H., and O. Kandler. 1972. Peptidoglycan types of bacterial cell walls and their taxonomic implications. Bacteriol. Rev. 36:407-477.

28. Schleifer, K. H., and R. Kilpper-Bälz. 1984. Transfer of Streptococcus faecalis and Streptococcus faecium to the genus Enterococcus nom. rev. as Enterococcus faecalis comb. nov. and Enterococcus faecium comb. nov. Int. J. Syst. Bacteriol. 34:31-34.

29. Schleifer, K. H., R. Kilpper-Bälz, J. Kraus, and F. Gehring. 1984. Relatedness and classification of Streptococcus mutans and "mutans-like" streptococci. J. Dent. Res. 63:1047-1050.

30. Schleifer, K. H., S. A. Meyer, and M. Rupprecht. 1979. Relatedness among coagulase-negative staphylococci: deoxyribonu- 
cleic acid reassociation and comparative immunological studies. Arch. Microbiol. 122:93-101.

31. Schleifer, K. H., and E. Stackebrandt. 1983. Molecular systematics of prokaryotes. Annu. Rev. Microbiol. 37:143-187.

32. Seelemann, M. 1954. Biologie der Streptokokken. Verlag Hans Carl, Nuremburg.

33. Stahl, E. 1967. Dünschichtchromatographie. Ein Laboratoriums handbuch, p. 298. Springer Verlag KG, Berlin.

34. Takayama, M., S. Itoh, T. Nagasaka, and I. Tanimizu. 1977. A new enzymatic method for determination of serum cholinecontaining phospholipids. Clin. Chim. Acta 79:93-98.

35. Trinder, P. 1969. Determination of glucose in blood using glucose oxidase with an alternative electron acceptor. Ann. Clin. Biochem. 6:24-27.

36. Welborn, P. P., W. K. Hadley, E. Newburn, and D. M. Yajko. 1983. Characterization of strains of viridans streptococci by deoxyribonucleic acid hybridization and physiological tests. Int. J. Syst. Bacteriol. 33:293-299. 